IJM

27,7

604

Received 7 February 2005

Revised 22 February 2006

Accepted 23 May 2006

\section{Economic performance and unemployment: evidence from an emerging economy}

\author{
Hakan Berument
}

Department of Economics, Bilkent University, Ankara, Turkey

Nukhet Dogan

Department of Econometrics, Gazi University, Ankara, Turkey, and

Aysit Tansel

Department of Economics, Middle East Technical University, Ankara, Turkey and Institute for the Study of Labor (IZA), Bonn, Germany

\begin{abstract}
Purpose - This article seeks to examine whether or not various macroeconomic policy shocks have different effects on overall unemployment and the unemployment by different levels of education in Turkey. These effects are assessed separately for male and female unemployment.

Design/methodology/approach - To examine the relationship, a quarterly VAR model with a recursive order is employed to estimate the effects of real GDP, price, exchange rate and interbank interest rate on unemployment for the period from 1988:01 to 2003:04.

Findings - Main findings indicate that monetary policy does not affect the total unemployment as well as the components of unemployment by educational level and by gender in Turkey. On the other hand, income policies, which include fiscal policies, and unemployment itself, might be the main factors that affect the behavior of total unemployment and its various components.

Research limitations/implications - These findings suggest that policy makers should concentrate on non-monetary policies to hamper the unemployment in Turkey.

Originality/value - The present study is the first empirical examination of the relationship between various macroeconomic policy shocks and the unemployment both across gender and education levels in a single study.
\end{abstract}

Keywords Unemployment, Gender, Education, Economic performance, Turkey

Paper type Research paper

\section{Introduction}

This article examines whether various macroeconomic policy instruments have different effects on overall unemployment and the unemployment by different levels of education in Turkey for the period from 1988:01 to 2003:04. These effects are assessed for male and female unemployments separately. The focus is on the unemployment by education levels and gender. During this period Turkish economy experienced four major crises. The first one was in 1991 and was due to the adverse effects of the Gulf

The authors would like to thank two anonymous referees of this journal for their valuable comments. They also acknowledge the financial support from the Turkish Academy of Science

(SBB-4024).
International Journal of Manpower Vol. 27 No. 7, 2006

pp. $604-623$

( E) Emerald Group Publishing Limited 0143-7720

DOI 10.1108/01437720610708248 
War. It created uncertainties in the exchange rate and as a result the real exchange rate depreciated by 8.3 percent. The second major shock occurred in 1994 due to the mismanagement of the domestic debt. A stabilization policy was put into effect in April of that year. Interest rate and the exchange rate soared. There was a devaluation of the Turkish lira by almost 70 percent. The economy contracted by approximately 6 percent. However, the recovery was quick and in the following year the growth rate was 8 percent. The third major shock was in 1999. During the first half of the 1999 the delayed effect of the Russian crisis on the Turkish economy was felt. In addition, in the second half of the 1999 two major earthquakes struck the eastern Marmara region, which is the industrial heartland of the country. There were substantial adverse effects on output and employment. The fourth major shock was the financial crisis of November 2000 followed by a more severe financial crisis in February 2001. This was the most severe shock in the history of the Turkish Republic. The GNP declined by nearly 9.6 percent in 2001. The effects of this crisis were both prolonged and widespread as compared to the previous crises. Although the economic growth picked up since then the unemployment rates remained very high. This is dubbed as "jobless growth".

Bulutay (1996) argues that unemployment rates across different education levels have different characteristics. For example, after the February 2001 crisis, the unemployment rate was 13.31 percent for the High School graduates, while it was only 4.08 percent for the literate without diploma. Moreover, the unemployment rates differed substantially between males and females. For instance, the unemployment rate for High School graduates were 20 percent for females and 11.47 percent for males. The unemployment rate for the literates without diploma were 1.53 percent for females and 7.16 percent for males. Therefore, in the analysis that follows we compare the effects of various shocks on female and male unemployment separately.

In this study, the specific exogenous shocks whose effects on unemployment are assessed include changes in output, exchange rate, prices and interest rate. Using a Vector Autoregression (VAR) specification, we estimated the effects of changes in various macroeconomic factors on overall unemployment and unemployment by education levels for the female and male labor force groups. These effects are estimated for the period 1988:01 to 2003:04.

The subject of this paper is related to four main strands of existing literature. First, there are theoretical studies that have examined the role of fundamental macroeconomic variables on unemployment rate. These studies are by Agenor and Aizenman (1999) and Daitoh (2003). Agenor and Aizenman (1999) theoretically analyzed the implications of fiscal and labor market policies on output, wages and unemployment in a general equilibrium model for a small open developing economy. They found that there is no close relationship in the short run between changes in output and the unemployment rate. Daitoh (2003) theoretically investigated how the low interest rate policy in the commercial banking sector affects the urban unemployment using a small open Harris-Todaro model. His results suggested that in a Harris-Todaro economy, where the agriculture plays a dominant role in the domestic employment and production, the financial liberalization aggravates the rate and volume of urban unemployment.

Second, the subject of this paper is related to the empirical literatures that explain the movement of skilled and unskilled unemployment rates. These are Nickell and 
IJM

27,7

606
Bell (1995, 1996), Jackman et al. (1997), Acemoglu (1998), Baker and Schmitt (1999), Røed (1999) and Song and Webster (2001). Nickell and Bell (1995, 1996) and Jackman et al. (1997) report ratios of the low-educated unemployment rate to the high-educated unemployment rate for several countries, revealing that higher relative unemployment rates for the low skilled are just as prevalent in the USA as in the major European countries. Their results show that both in the USA and Europe unbalanced demand and supply changes raised unskilled unemployment and reduced skilled unemployment. Acemoglu (1998) offered a model where firms decide on the types of jobs they create and the search for suitable workers. He concluded that an increase in the skill biased technical change can create a qualitative change in the composition of jobs, increasing the demand for skills, wage inequality and the unemployment rates for both groups. Baker and Schmitt (1999) considered various explanations provided for the increase in European unemployment over the last three decades. They suggested an alternative explanation. According to their findings the increase in unemployment was not concentrated among the least skilled, as the previous studies claimed. Instead, workers across all skill and education levels have experienced a rise in unemployment. Røed (1999) examined the relationship between skills, wages and unemployment. His results indicate that the effects on relative unemployment rates of skill-neutral shocks are almost negligible compared to those following from skill-biased shocks. Song and Webster (2001) find that the estimated relationship between unemployment and vacancies - the Beveridge curve is flatter and closer to the origin for the skilled workers than for the unskilled workers, and that the unemployment replacement rate shifts the Beveridge curve for the unskilled workers but not for the skilled workers.

Third, the paper relates to the large labor market literature on male-female differentials. Feminist economists have used gender as a category of analysis especially at the micro and macro levels[1]. This is an example of gender mainstreaming at the conceptual, theoretical and empirical levels, which then makes it possible to formulate gender-aware economic policies. However, while these ideas have been emphasized in the labor market literature, there has been very little analysis of their consequences in unemployment.

Last, the papers most similar to ours are by Zavodny and Zha (2000) and Algan (2002). Zavodny and Zha (2000). They examined the relationship between monetary policy and the race-specific unemployment rates in the USA and concluded that the black unemployment rate does respond slightly differently than the overall unemployment rate to macroeconomic variables. Algan (2002) examined the response of unemployment to aggregate demand, aggregate supply shocks using a structural VAR model for France and the USA. He observed that the aggregate demand, aggregate supply framework is well suited for the USA but poorly explains the French labor market. Our study assesses the effects of various macroeconomic shocks on the various components of unemployment by using the Turkish data. The present study is the first empirical examination of the relationship between macroeconomic policy instruments and the unemployment across gender and education levels. There are various advantages of using the Turkish data. First, Turkey is one of the predominant emerging markets. Therefore, this relationship for Turkey can be considered as a representative one for the other emerging markets. Second, Turkish financial and labor markets are not heavily regulated. Therefore, economic shocks are transmitted to the labor market easily. Third, high variability of 
the Turkish economic variables decreases the Type-II error - the error that is made when an incorrect null hypothesis is not rejected. Even if there is a behavioral relationship between unemployment and other macroeconomic variables, then detecting this relationship will be easier because of the high variability of the macroeconomic variables[2]. Main findings of this paper indicate that positive income and price shocks reduce the unemployment for the Less Than Primary School and the Primary School categories while they increase the unemployment for the High School and Higher Education graduates both in the short and the long run. Moreover, interbank interest rate does not have a statistically significant effect in the long run on any type of unemployment. On the other hand, exchange rate depreciation increases the female unemployment particularly for the Less Than Primary School and the Primary School categories. However, the impacts of all four shocks were largest on the female Less Than Primary School unemployment. The study suggests that not the monetary policy but the income policy variables affect the total unemployment and its components by education level and gender.

This paper is organized as follows. The next section analyzes the trends in the overall unemployment rate and the unemployment rates by education levels for males and females, in Turkey. The data used in this study are also described in Section 2. The econometric model used to estimate the relationship between various macroeconomic factors and the unemployment is explained in Section 3. Estimation results are presented in Section 4. Discussion of the results and conclusions appear in Sections 5 and 6 respectively.

\section{Trends in unemployment rates and the data}

We first give the evaluation of per capita nominal GDP growth rate and exchange rate during 1988-2003 in Figure 1. GDP growth rate declined to 0.6 in 1991 and increased to 1 in 1995. On the other hand, exchange rate growth (depreciation) declined 0.012 and increased to 0.16 in 1993. However it fell down to -0.3 during the 1994 crisis and reached its peak of 0.2 in 1995 . With the 1999 crisis, both per capita nominal GDP and depreciation decreased to 0.5 and -0.07 , respectively. They declined to 0.4 and -0.3 during the 2001 crisis and increased immediately after the crisis.

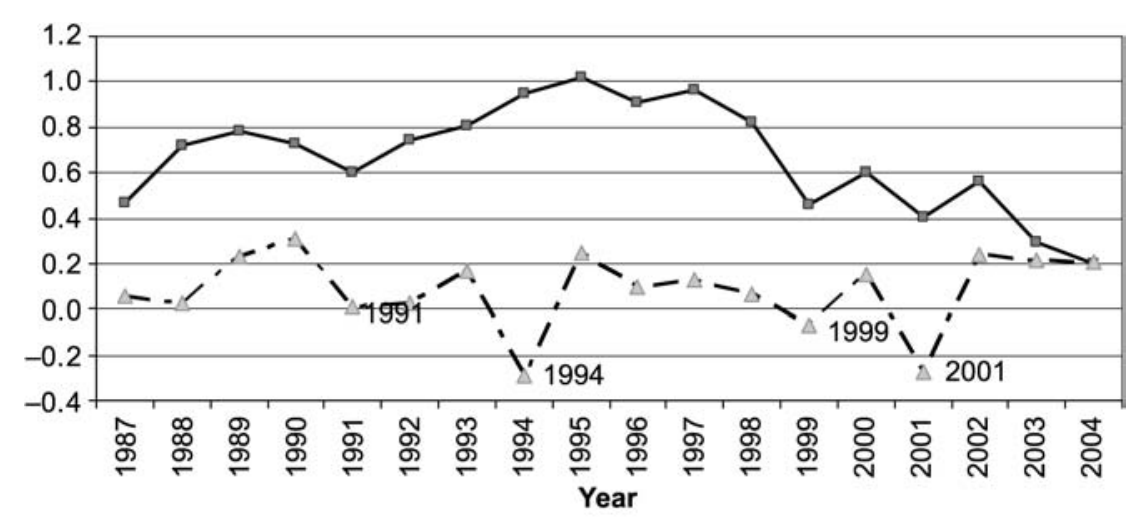

$\longrightarrow$-Per Capita Nominal GDP — - Exchange Rate

\section{Economic performance}

607
Figure 1. Per capita nominal GDP growth rate and exchange growth rate 
IJM

27,7

608
In order to visualize the evolution of the unemployment rate, we plot the rates by gender over the 1988-2003 period in Figure 2. According to the State Institute of Statistics of Turkey (SIS), unemployed are defined as all persons 15 years of age and over who are not employed during the reference period, who have taken specific step(s) to obtain a job during the last six months and are available to start work within 15 days (see SIS, 2004). The Figure shows the biannual rates before the 2000 and the quarterly rates for the 2000 and after in accordance with the data availability. It is believed that the unemployment rate should follow the trends in the economy. However, it is not possible to see the impact of the major shocks on the unemployment rate with the biannual data. In contrast the quarterly rates reflect the effects of the 2001 crisis and the ensuing recession.

Figure 2 shows that the total unemployment rate follows the trends in the male unemployment rate. Female unemployment rate shows fluctuations over time, although following the same trend. There are some increases in the male unemployment rate in 1994 and then in 1999, but the increasing trend is evident after 2000 due to the effect of 2001 crisis and the recession that followed.

Unemployment rates by education levels are shown in Figure 3 for females and in Figure 4 for males. Figure 3 shows that the unemployment rate of the female university graduates is above the average unemployment rate. Another observation is that the unemployment rates of the Junior High School and Vocational High School graduates are more cyclical than the unemployment rates of the other education levels. Figure 4 indicates that for the period between 1994 and 1997 male unemployment rates showed a steady decrease in all education levels. However, after the 2001 recession, the male unemployment rate increased substantially for all education levels. These figures indicate that the unemployment rate of High School graduates is higher than that of the

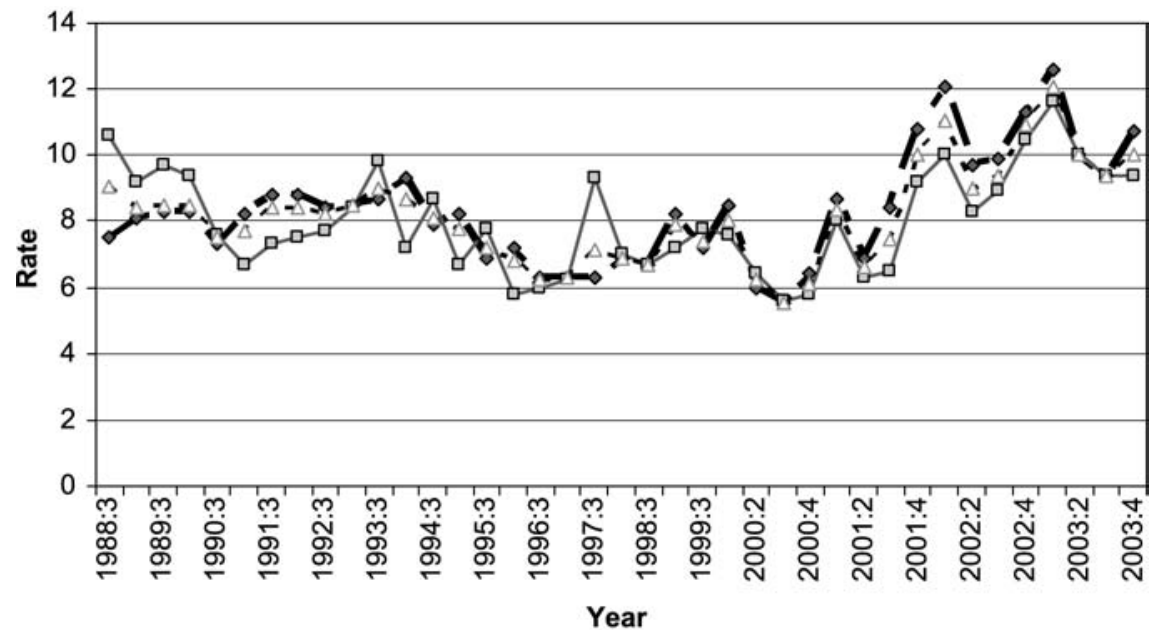

Figure 2.

Unemployment rate by gender

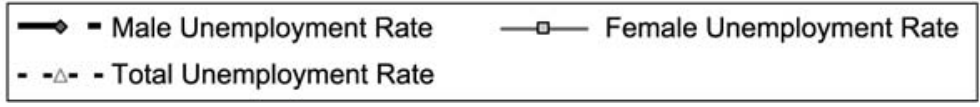




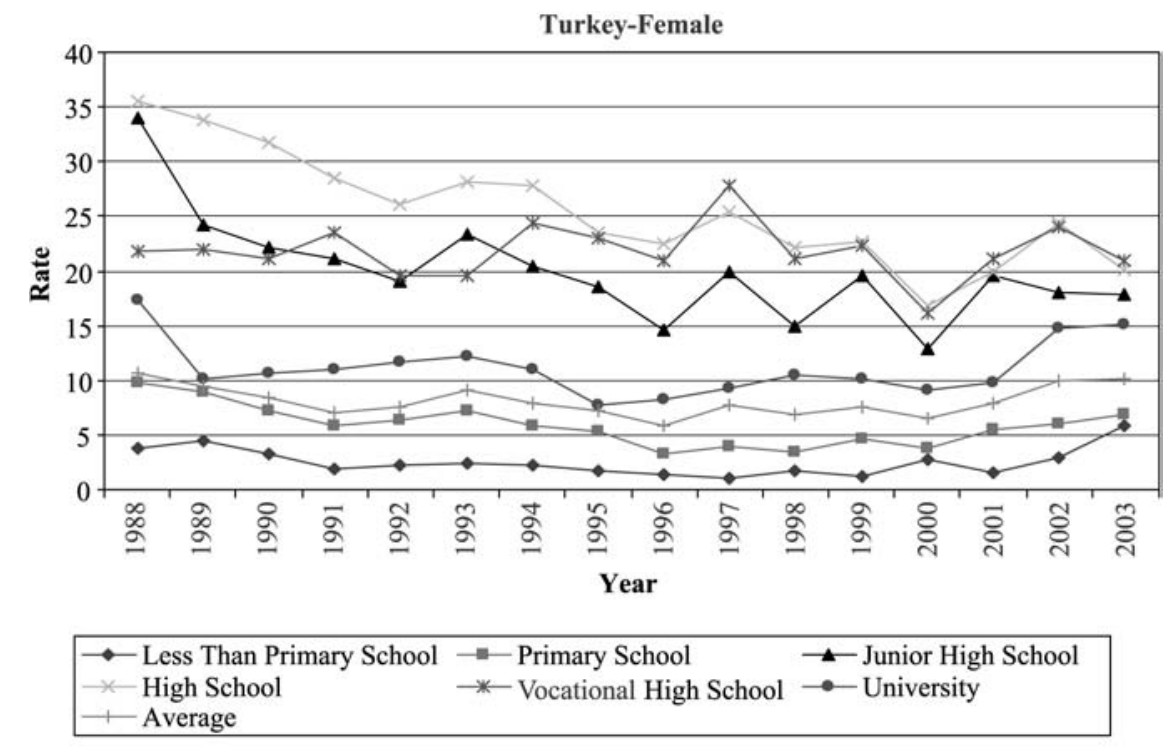

Notes: Less Than Primary School includes the illiterates plus the literate without diploma
Economic performance

609
Figure 3.

Female unemployment rate by educational level
Turkey-Male

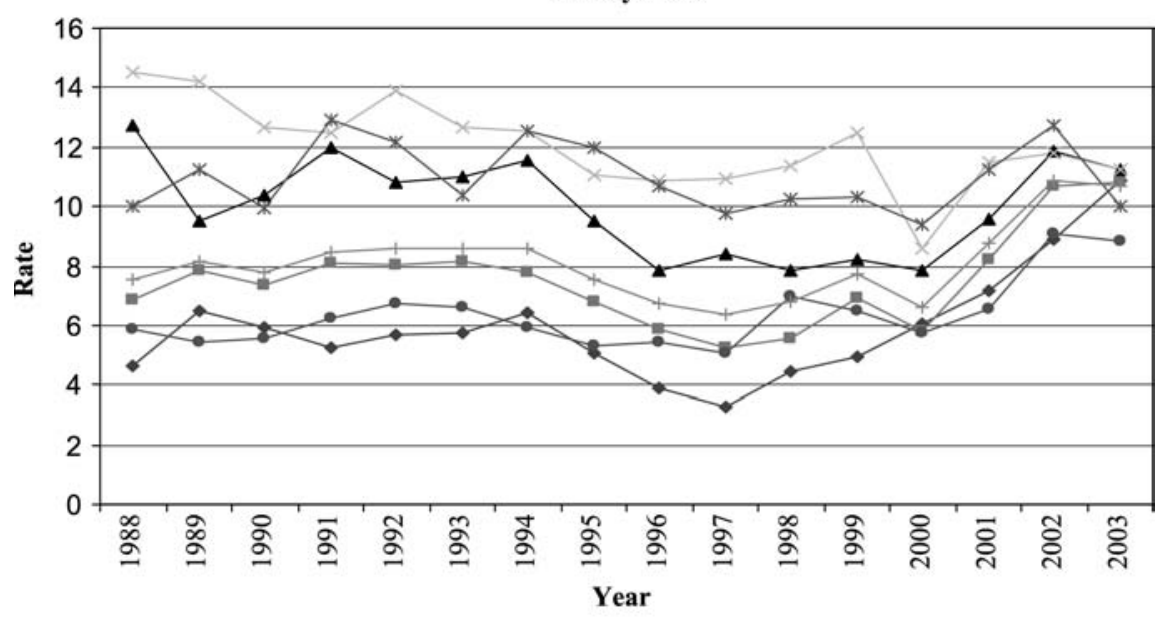

Figure 4. Male unemployment rate by educational level 
IJM

27,7

610

other education levels for both males and females. Further, the unemployment rate of the university graduates increased sharply after the 2001 crisis. It is well known that even the graduates of the prestigious universities were adversely affected by this crisis. In 2004 the unemployment rate of educated youth was 30 percent.

Table I provides the unemployment levels across educational categories for both genders for the fourth quarter of the year 2003. In this table "Illiterates" indicate individuals who do not have any schooling. In the Turkish educational system Primary

School graduates acquire five years of schooling. Junior High Schooling takes three years. The recent educational reform combined the primary and the junior high schooling so that the combined eight years is now the compulsory level. Vocational High School takes three or four years. High School takes three years. Finally University education provides programs that take two or four years of study. The Primary School unemployment figures are the largest for both genders. They constitute 52 percent and 31 percent of the total unemployment for male and females. For both genders, Higher Education unemployments are the second largest. Male High School unemployment level is the third highest. The two lowest unemployment levels are observed for the illiterate and literate without any diploma for both genders. Thus, we may claim that for both genders rates and levels of unemployment have the same ordering across education classifications.

In our empirical analysis, quarterly data from 1988:01 to 2003:04 are used. Macroeconomic indicators are real $\mathrm{GDP}(\mathrm{Y})$, price $(\mathrm{P})$, exchange rate $(\mathrm{EXCH})$, interbank interest rate (INTERBANK) and money supply (M1) plus repo (M). They are obtained from electronic database system of the Central Bank of the Republic of Turkey (CBRT), (CBRT, 2004). The other data set, which includes the total unemployment and the unemployment by education and gender, were compiled from the Household Labor Force Surveys (HLFS), which was conducted by the State Institute of Statistics Prime Ministry Republic of Turkey (SIS, 2004). The aim of the HLFS studies was to produce data on the labor force participation and the unemployment rates and the number of persons employed, underemployed and unemployed. During the period 1988-1999, HLFS were conducted twice a year in April and October In the applications covering this period, households which ranged from 11,160 to 22,320 were interviewed on a national level. In the year 2000, application frequency, sample size, estimation dimension, questionnaire design and some other aspects of the HLFS were changed. Since 2000, the households are being followed quarterly. During this period about

Table I.

Unemployment by gender and education for 2003:4 (in thousands)

\begin{tabular}{lrr}
\hline & Male & Female \\
\hline Total unemployment & 1,807 & 588 \\
Illiterate & 41 & 53 \\
Literate without any Diploma & 46 & 4 \\
Primary school & 934 & 181 \\
Junior high school & 256 & 46 \\
Vocational high school & 128 & 66 \\
High school & 213 & 92 \\
Higher education & 163 & 138
\end{tabular}

Source: State Institute of Statistics, Household Labor Force Survey 
23,000 households were selected in the new sampling design for each quarter. Since we do not have quarterly data for the 1988-1999 period, we estimated the missing quarters by using an interpolation method[3]. Between 1988 and 1999, the reference period was the fourth week of April and October, starting with Monday and ending with Sunday. Since 2000 the seven days before the first application of the survey are being used as the reference period.

In this paper, real GDP is used as a measure of income. Price level is measured by the GDP deflator. The Exchange rate is defined as Turkish lira value of the official currency basket which is composed of 1 USD and 0.77 Euro. Interest rate is the interbank's overnight interest rate. Finally, M1 + repo are taken as the measure of money supply. There are two reasons for including the repo in the money supply aggregates (Berument, 2007). First, most of the repo transactions were overnight, hence this money aggregate was liquid. Second, agents prefer to repo their savings rather than open deposit accounts since the repo rates are considerably higher.

\section{Model specification}

In our empirical analysis, we use a measure of shocks to macroeconomic policy which was developed in Christiano et al. (1998). Christiano et al. (1998) identify a policy shock with the disturbance term in a regression equation of the form:

$$
S_{t}=f\left(\Omega_{t}\right)+\varepsilon_{t}^{s}
$$

where $S_{t}$ is the policy instrument, $f$ is a linear function, $\Omega_{t}$ is the information set available to the economic authority at time $t$. The random variable, $\boldsymbol{\varepsilon}_{t}^{\mathcal{s}}$, is a serially uncorrelated policy shock that is orthogonal to the elements of $\Omega_{t}$. The orthogonality restriction on $\varepsilon_{t}^{s}$ corresponds to the assumption that the policy variable is contemporaneously affected by the date $t$ variables in $\Omega_{t}$ but these variables are not contemporaneously affected by the monetary policy shock. Christiano et al. (1998) offered three economic interpretations about these policy shocks. First, $\varepsilon_{t}^{s}$ reflects exogenous shocks to the preferences of the monetary authority. Second, the exogenous variation in policy can arise because of the strategic consideration. Third, the source of exogenous variation in Central Bank policy could reflect various technical factors.

In practice, the coefficients on the current and lagged values of the fitted residuals in equation (1) can measure the impulse response of a variable to a policy shock. This procedure is asymptotically equivalent to the one based on fitting a particular Vector Autoregression (VAR). VAR method can be written in the standard form:

$$
Z_{t}=A_{1} Z_{t-1}+A_{2} Z_{t-2}+\ldots+A_{q} Z_{t-q}+u_{t}
$$

where $E\left(u_{t} u_{t}^{\prime}\right)=V$ and $u_{t}$ is assumed to be serially uncorrelated. The fundamental economic shocks, $\varepsilon_{t}$ are assumed to be related to the VAR disturbances by:

$$
B_{0} u_{t}=\varepsilon_{t}
$$

where $B_{0}$ is an invertible, square matrix. $E\left(\varepsilon_{t} \varepsilon_{t}^{\prime}\right)=D$, where $\mathrm{D}$ is a diagonal matrix. Premultiplying (2) by $B_{0}$ we get:

$$
B_{0} Z_{t}=B_{1} Z_{t-1}+\ldots+B_{q} Z_{t-q}+\varepsilon_{t}
$$

\section{Economic performance}

611 
IJM

27,7

612

Here $B_{i}$ is a $k \times k$ matrix of constant $\mathrm{i}=1, \ldots, \mathrm{q}$ and

$$
A_{1}=B_{0}^{-1} B_{1} \quad \mathrm{i}=1, \ldots, \mathrm{q}
$$

where $V=B_{0}^{-1} D\left(B_{0}^{-1}\right)^{\prime}$.

So, $\gamma_{h}$ represents the response of $Z_{t+h}$ to a unit shock in $\varepsilon_{t}$. In order to compute $\gamma_{h}$, let $\tilde{\gamma}_{h}$ be the solution to following difference equation:

$$
\tilde{\gamma}_{h}=A_{1} \tilde{\gamma}_{h-1}+\ldots+A_{1} \tilde{\gamma}_{h-q} \mathrm{~h}=1,2, \ldots
$$

with initial conditions, $\tilde{\gamma}_{0}=I, \tilde{\gamma}_{-1}=\tilde{\gamma}_{-2}=\ldots=\tilde{\gamma}_{-q}=0$.

Then,

$$
\gamma_{-1}=\tilde{\gamma}_{h} B_{0}^{-1}, \quad \mathrm{~h}=0,1
$$

The response of the $j$ th component of $Z_{t+h}$ to a unit shock in the $l$ th component of $\varepsilon_{t}$ is the $(j, l)$ element of $\gamma_{h}$.

According to the equation (7) we need to know the $A_{i}$ 's and $B_{0}$ in order to compute the impulse response function. We estimate the $A_{i}$ 's and $B_{0}$ in (2) and (5) by applying the ordinary least squares method to equation to (2). In the absence of restrictions on $B_{0}$ there are many solutions to equation (5). We impose restrictions on $B_{0}$ by assuming that $B_{0}$ is a lower triangular matrix-Cholesky decomposition[4].

A quarterly VAR model is used to estimate real GDP, price, exchange rate, interbank interest rate, money supply and the unemployment relationship for the period 1988:01-2003:04. In order to address the seasonality, seasonal dummies are included in the VAR as exogenous variables. For the three domestic financial crises in April 1994, November 2000 and February 2001 three exogenous dummy variables are also included. The coefficients on the dummy variables for the 1991 and 1999 shocks to the economy were not statistically significant and therefore, excluded from further analysis. Finally, because of the change in the definition of M1 and repo, one more dummy variable is included in the VAR model after 1996. The model is estimated using log levels for all data except the interbank interest rate. The lag length of two for the VARs is determined by the Schwartz Bayesian selection criterion.

The order of the variables in the VAR system is important. Ordering implies that any variable in the system affects all the remaining variables that precedes that variable but not affected by the any preceding variables contemporaneously. However, each variable affects the others with a lag. Our variables are ordered as real GDP, price, exchange rate, interbank interest rate, M1 + repo and unemployment. Income and price are ordered first as an information assumption then we impose the restriction that they are not affected by the interbank rate but do affect the interbank rate contemporaneously. This imposes extreme information assumption that central bank knows income and prices before setting up its interbank rate as an indicator of monetary policy. Most papers such as Christiano and Eichenbaum (1992), Eichenbaum and Evans (1995), Strongin (1995), Bernanke and Blinder (1992), Bernanke and Mihov (1998), Gertler and Gilchrist (1994) and Christiano et al. (1998) assume this type of ordering while some other papers use a different type of ordering. For example Sims and Zha (1995) and Leeper et al. (1996) assume that central bank does not look at the contemporaneous income and price level when setting its policy instrument. Moreover, Berument (2007) argues that the CBRT tend to change the interbank interest rate rather than the exchange rate depreciation 
daily for its monetary policy setting. The CBRT announced the exchange rate every morning and depreciated the local currency against the basket every day by constant for the most of our sample. Therefore, the public knows the monthly depreciation rate after the first or second business day of each month, but the interest rate is subject to change every day. Thus, we order the exchange rate before the interbank interest rate. Finally we order money supply at the end but before the unemployment. This choice is motivated by Cooley and Hansen (1989, 1997), King (1991), Christiano (1991) and Christiano and Eichenbaum (1995). They assume that all movements in money are affected by economic variables. In this paper, it is also assumed that the money supply and unemployment are not predetermined relative to the policy shocks. Furthermore, this ordering implies that monetary policy actions (change in interest rate) have contemporaneous effects on money supply and unemployment. As a consequence, when we order the variables as real GDP, price, exchange rate, interbank interest rate, $\mathrm{M} 1+$ repo and unemployment, the resulting evidence is consistent with the nature of macroeconomic policy agreements.

\section{Empirical evidence}

Figures 5 to 9 report the impulse responses of one standard deviation shock for the core VAR model that include real GDP, price, exchange rate, interbank interest rate, M1 plus repo and unemployment by educational statuses with two lags for 12 periods. The error bands for the impulse responses are drawn at $\alpha=10$ percent level. The standard errors are calculated by bootstrapping with 500 draws. Impulse responses are represented with the middle lines in the figures. The upper and lower lines are for the confidence bands. Accordingly, if the confidence bands include the horizontal line (that is the impulse is zero), then the null hypothesis that there is no effect of policy shocks on unemployment cannot be rejected. Therefore, including the horizontal line for the particular time period obtained in this manner is interpreted as the evidence of statistical insignificance. However, in order to save space, we report the impulse responses to four shocks - real GDP, price, exchange rate, interbank interest rate rather than six variable shocks[5].

Figure 5A plots how a one standard deviation shock given to the four macroeconomic variables affect the behavior of female unemployment[6]. Figure 5B repeats the exercise for male unemployment. For expositional purposes, we will first interpret how the unemployment changes with income shocks. The upper left graphs, in Figures $5 \mathrm{~A}$ and $5 \mathrm{~B}$ show how one standard deviation shock to income decreases female and male unemployment for the whole period. All responses are statistically significant except for the initial level for females and males and after the eighth quarter for females. This result is consistent with various econometric studies such as by Algan (2002) who finds that a positive demand shock decreases the unemployment rate permanently in France and the USA. However this effect is not statistically significant at the 10 percent level for France. Similarly, Zavodny and Zha (2000) find that tight monetary policies (negative demand shock) increase the unemployment. Hence, our results are parallel with the results of these two studies.

Next we elaborate on how unemployment is affected by income innovations across the education levels. We consider "Less than primary school", "Primary education", "High school" and "Higher education"[7]. In order to save space, we will elaborate only the statistically significant estimates.

\section{Economic performance}

613 
IJM

27,7

614 (a) On Female Unemployment

Effects of Shocks on Unemployment_f
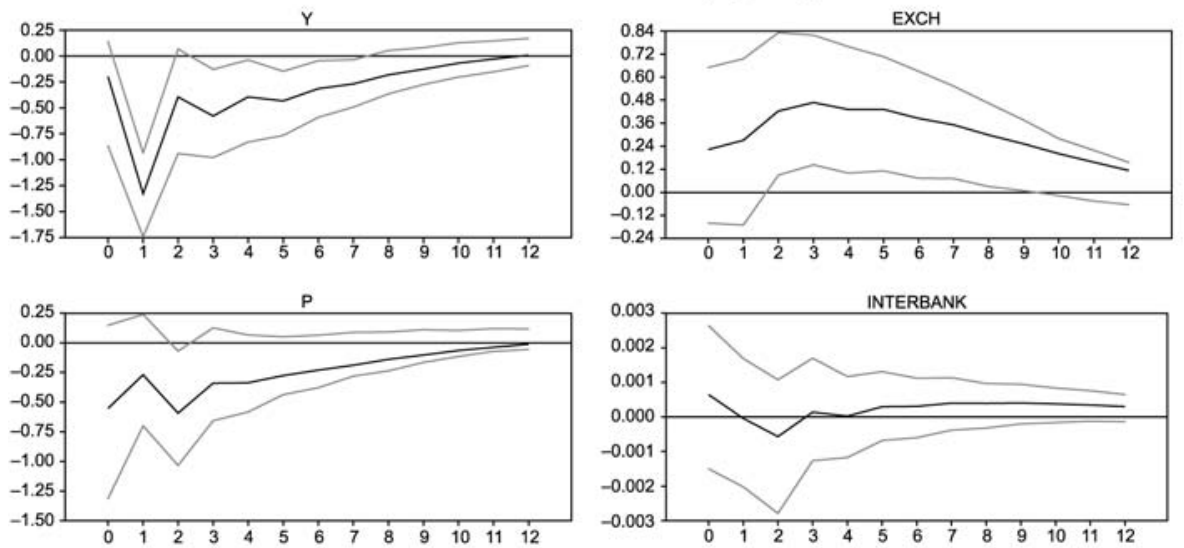

(b) On Male Unemployment
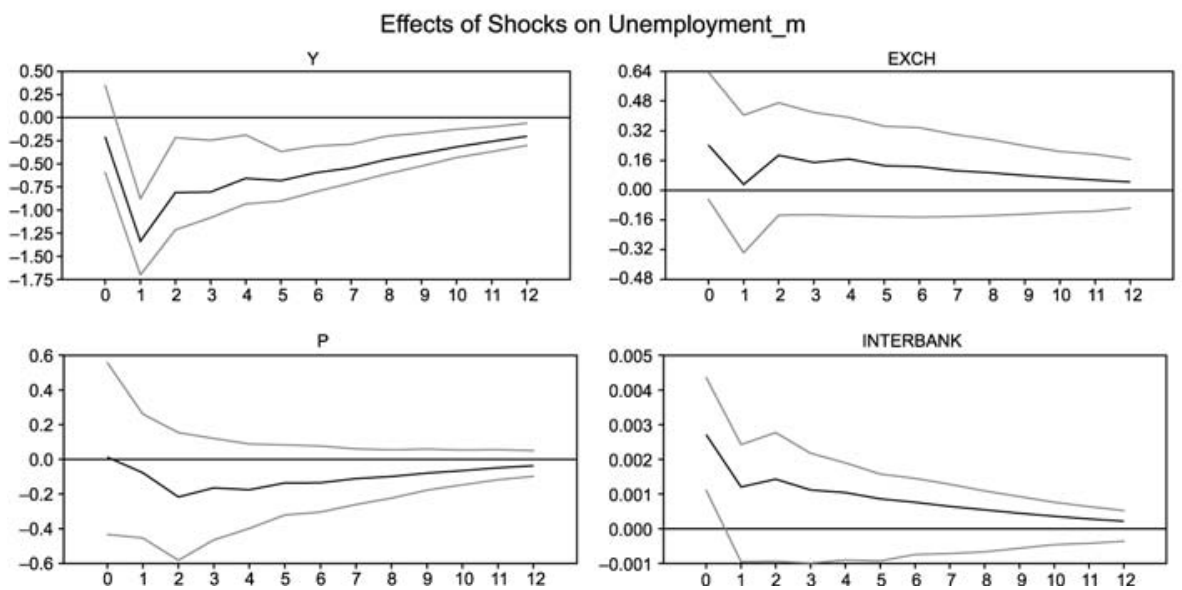

Figure 5.

Responses of unemployment to economic shocks

Figures $6 \mathrm{~A}$ and $6 \mathrm{~B}$ show that a one standard deviation shock to income decreases female and male unemployment of "Less than primary school" for all of the periods. They are statistically significant except that for female initial level and after 11 periods; and for male only after 11 periods. In Figures 7A and 7B, the responses of female and male unemployment for the primary education graduates are negative and statistically significant except at initial level and after the fifth quarter for females and the tenth quarter for males. Figure 8 reports analysis for the high school unemployment. Figure $8 \mathrm{~B}$ shows that an income shock increases the male unemployment for the initial level and after the sixth quarter and decreases it between the first and the sixth quarters. However only the decreases between the periods 1 and 2 and the increases after the eighth quarters are statistically significant. 
(a) On Female Unemployment
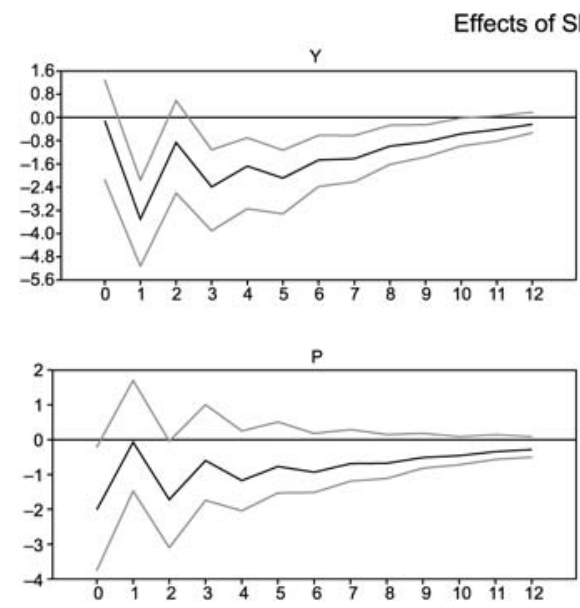

(b) On Male Unemployment
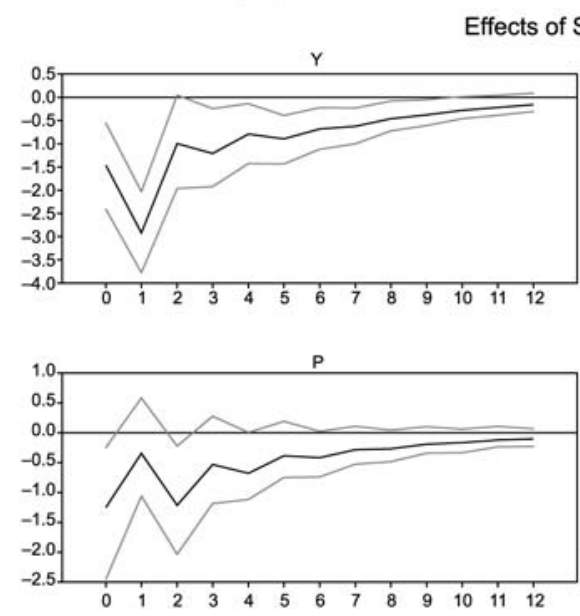

EXCH

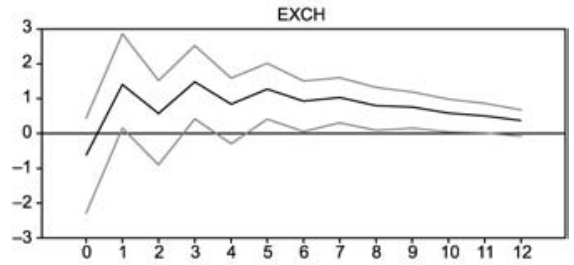

INTERBANK

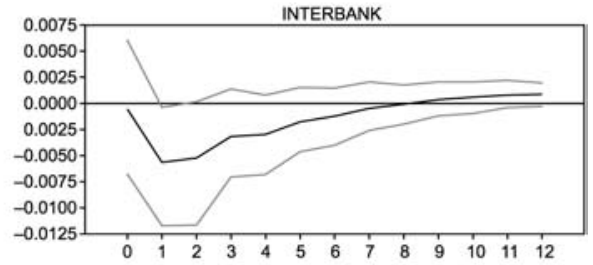

615

Figure 6.

Responses of less than primary school unemployment to economic shocks

Figures $9 \mathrm{~A}$ and $9 \mathrm{~B}$ report the response of higher education unemployment for female and male graduates respectively. Female and male unemployments have negative and statistically significant impact for the periods 1 and 2 and for the initial periods, respectively. On the other hand, they have positive and statistically significant impact after the tenth quarter. In sum, the income shock decreases the unemployment for the "Less than primary school" and "Primary education" for all of the periods. While the income shock affects the male high school unemployment both in the short and the long run, it does not affect the female high school unemployment in either the short or the long run. Moreover, income shock affects female and male higher education unemployment both in the short and the long run. Finally, we observe that the biggest impact is on the female less than primary school unemployment. 
IJM

27,7

616

Figure 7.

Responses of primary education unemployment to economic shocks (a) On Female Unemployment
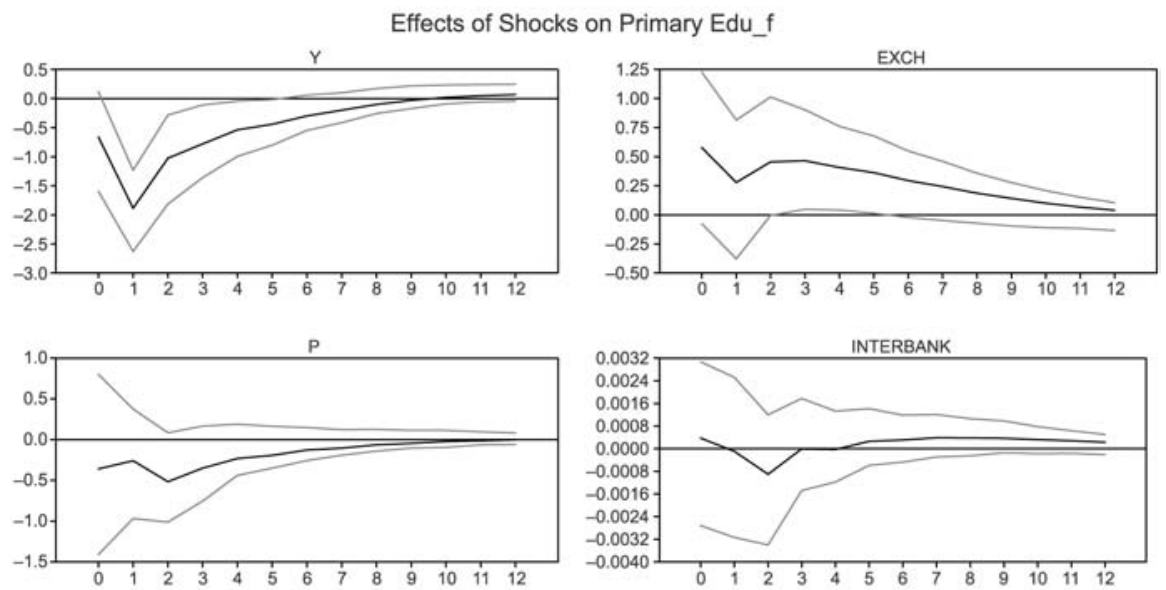

(b) On Male Unemployment
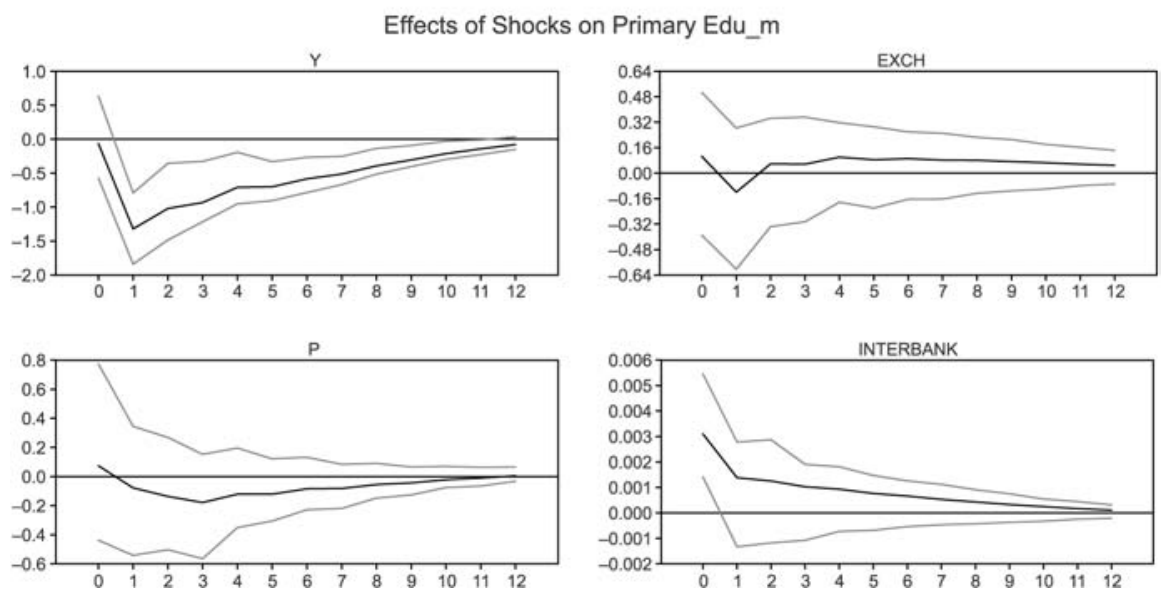

Turkey is a small open economy. It mostly imports raw materials, intermediate products, and machine and equipment for its investment. Therefore, it is plausible that exchange rate movements affect the state of the economy adversely and increase the unemployment (see Berument and Pasaogullari, 2003, on a discussion of the effect of exchange rate depreciation on the Turkish economic performance). On the other hand, higher exchange rate encourages exports and discourages imports, and boosts the economy. Therefore, next we assess how unemployment by gender and various levels of education respond to the exchange rate innovations.

Figure 5A shows that a one standard deviation shock to exchange rate increases the female unemployment for all of the periods. However, only the periods between 2 and 9 are statistically significant. In Figures 6-9, the upper middle graph shows the response of unemployment by different educational levels to the exchange rate innovation. In 
(a) On Female Unemployment
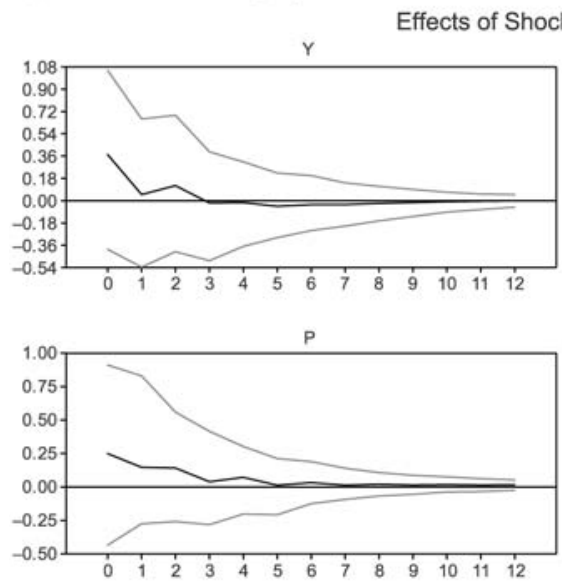

(b) On Male Unemployment

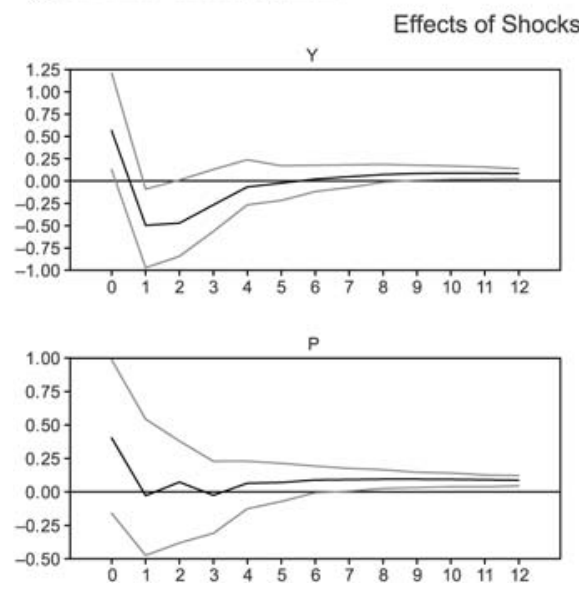

EXCH
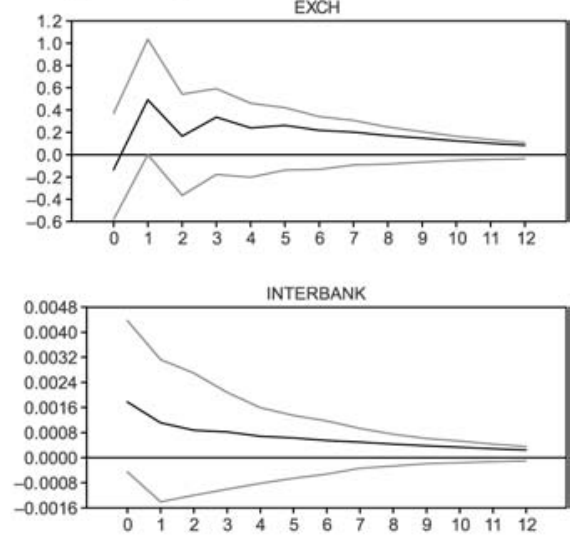

Figure 8.

Responses of high school unemployment to economic shocks

Figure $6 \mathrm{~A}$, a shock on exchange rate has positive and statistically significant affect on female less than primary school unemployment during the first, the third and after the fifth quarters. Figure 7A reports the results for female primary education unemployment. The increases in unemployment are observed for all of the periods but the evidence is statistically significant only for the periods between 2 and 5 . In Figure 8B, the response of male high school unemployment is positive and statistically significant only for the first quarters. In summary the exchange rate shock affects female less than primary school, primary education and male high school unemployment in the short run. Furthermore, the biggest impact is observed on female less than primary school unemployment.

We next assess the impact of changes in price on unemployment by different educational levels and gender. Figures $5 \mathrm{~A}$ and $5 \mathrm{~B}$ show that a one standard deviation shock to price decreases the female and male unemployment for all of the periods. 
IJM

27,7

618

Figure 9.

Responses of higher education unemployment to economic shocks (a) On Female Unemployment

Effects of Shocks on Higher Edu_f
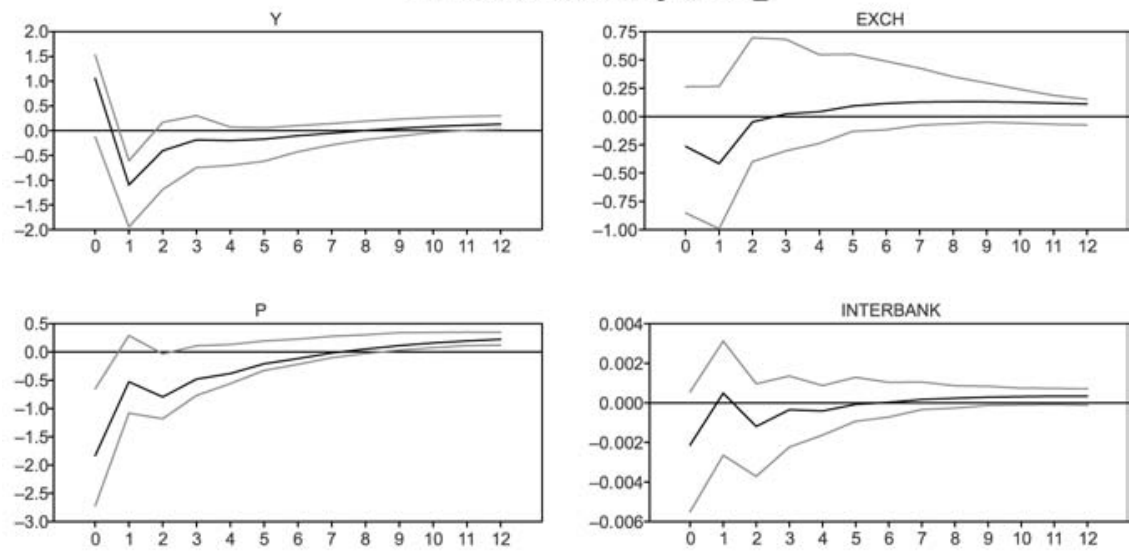

(b) On Male Unemployment

Effects of Shocks on Higher Edu_m
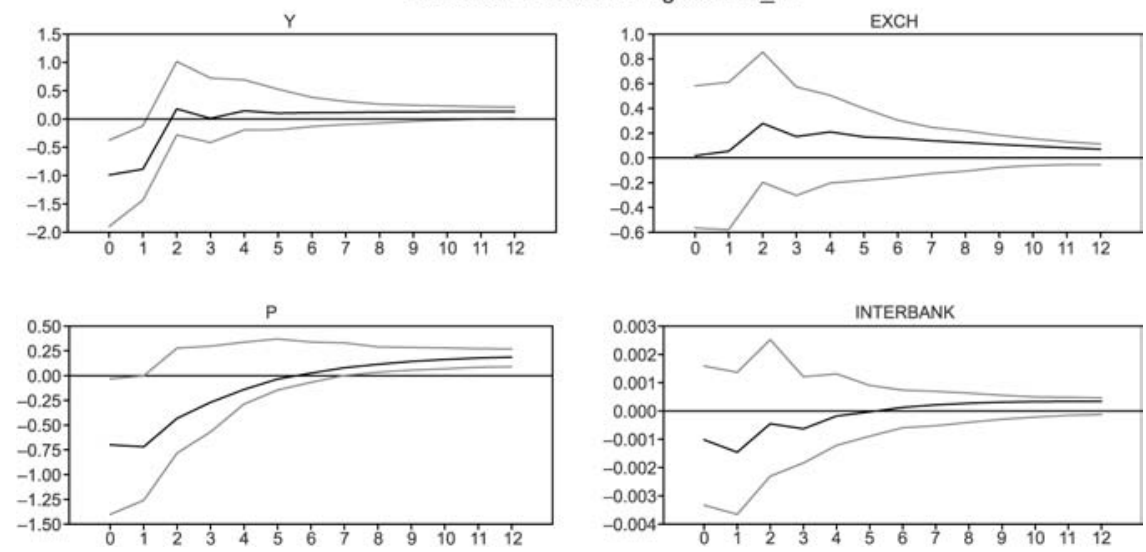

However none of them are statistically significant In Figures $6 \mathrm{~A}$ and $6 \mathrm{~B}$ the female and male less than primary school unemployment responses are given respectively. They are both negative and statistically significant for the initial level and for the second quarter. Figure $8 \mathrm{~B}$ reports that one standard deviation shock to price increases unemployment for high school graduates for all of the periods. These increases are statistically significant after the seventh quarter. In Figures 9A and 9B we observe that the responses of female and male Higher Education unemployment are positive and statistically significant after the eighth quarter. Main consequences of a price shock can be summarized as follows. First, price shock affects female and male less than primary school unemployment in the short run. Second, same shock affects male high school, female and male higher education unemployment in the long run. Third, one standard deviation shock to price has the biggest impact on female less than primary school unemployment. 
We now interpret the innovation to the interbank interest rate. Positive interbank interest rate innovations are often taken as an indicator of tight monetary policy Christiano et al. (1998). Figure 5B shows the effect of one standard deviation shock to interbank interest rate on male unemployment. Male unemployment increases for all of the periods but the increase is statistically significant only for the initial level. The evidence on female unemployment is not statistically significant. In Figure 6A the response of female less than primary school unemployment is negative and statistically significant for the first quarter. Figures $7 \mathrm{~B}$ and $8 \mathrm{~B}$ report that one standard deviation shock to interbank interest rate increases for males the primary education and high school unemployment. These increases are statistically significant at the initial level. These results indicate that interbank interest rate affects only female less than primary school, male primary education and male high school unemployment in the short run. The biggest impact is observed on female less than primary school unemployment.

As a robustness test, we also performed the analysis by ordering the variables as interbank rate, exchange rate, real GDP, price, M1 + repo and unemployment. These results are not reported but are available from the authors on request. The basic conclusions of the paper are robust under the alternative ordering.

\section{Discussion}

The responses of female and male unemployment to the various economic shocks are similar. The responses of most of the unemployment classifications to economic shocks are not similar across the different education levels. For example the responses of the high school and higher education unemployment to income and price shocks are different from the less than primary school and primary education unemployment. Income and price shocks lead to a rise in the high school and higher education unemployment but they lead to a fall in the less than primary school and primary education unemployment. These are statistically significant in both the short and the long run for the income shock and in the long run for the price shock. These may suggest that not the supply but demand side shocks were the main determinants of high school and higher education unemployment in the past. However, the economic conditions not only affect the level of employment but also the labor force participation (see Tansel, 2002). If labor force participation increases faster than employment itself then unemployment increases. As a separate analysis, we look at the effects of the economic shocks on high school and higher education employment (not reported but available on request). The empirical evidence suggests that with positive shocks in the price and income there is an increase in the high school employment which is statistically significant. The higher education employment decreases contemporaneously with income shock but this is not statistically significant. These may suggest that an increase in unemployment is not necessarily due to a decrease in employment but it may also be due to a rise in the labor force participation.

It is also important to recognize that shock to interbank interest rate does not have a long-run effect on any type of unemployment. However, the male primary education and high school unemployment and female less than primary school unemployment both respond to this variable in the short run. Exchange rate does not have statistically significant effect on any class of unemployment in any horizon but it affects positively the female less than primary school, primary education and male high school unemployment. These effects of exchange rate exist only for the first period. The Central

\section{Economic performance}

619 
IJM

27,7

620

Bank of the Republic of Turkey used these two variables as policy tools in the past. Since none of these variables have statistically significant effects on unemployment in the long-run, this clearly suggests the ineffectiveness of the monetary policy in the long-run. However, in the short-run, the effect is limited. Therefore, this study suggests that the policies of the Turkish Central Bank are not responsible for the high and persistent levels of unemployment Turkey has been experiencing.

\section{Conclusion}

This study examines whether the exogenous shifts in income, exchange rate, price and interbank interest rate policies have differential effects on the overall unemployment and the unemployment by different levels of education and gender in Turkey. In order to investigate the relationship between various macroeconomic variables and unemployment, the VAR method is applied for the 1988-2003 period using quarterly data.

The empirical evidence suggests that positive income shock decreases total unemployment. This finding is consistent with Algan (2002) and Zavodny and Zha (2000). We further find that positive income and price shocks increase the high school and higher education unemployment and decrease the less than primary and primary education unemployment. These are statistically significant in the short and long run for income shock and in the long run for the price shock. With regards to the exchange rate innovations the results indicate that unemployment increases during the first periods which are statistically significant for the female less than primary school, primary education and male high school unemployment. Next, the shocks to interbank interest rates do not have a long-run effect on any type of unemployment; only the male primary education and high school unemployment and the female less than primary school unemployment respond to this variable in the short run. There are some gender differences in the impact of shocks on unemployment mainly in the levels of significance. Lastly, the one standard deviation shock to all variables have the biggest impact on the female less than primary school unemployment. The results suggest some gender differences and statistically significant differences by education levels.

In conclusion we can say that monetary policy do not affect the total unemployment as well as the components of unemployment by educational level and gender in Turkey. On the other hand, income policies (including fiscal policies), and the unemployment itself, might be the main factors that affect the behavior of total unemployment and its various components. These findings suggest that policy makers should concentrate on non-monetary policies to hamper the unemployment in Turkey.

\section{Notes}

1. See Beneria and Sen (1981), Elson and Pearson (1981), Bergmann (1974), Cagatay (1998), Sawhill (1977), Ferber and Birnbaum (1977), Hartmann (1979), Young et al. (1981), Folbre (1982, 1986, 1994) Agarwal (1994), Ferber and Nelson (1993), Sen (1990) among many examples. Also see Feminist Economics, the official journal of the International Association for Feminist Economics (IAFFE), an association founded in 1992. IAFFE maintains a home page at www.facstaff.bucknell.edu/jshackel/iaffe

2. Neter et al. (1985, p. 71) specify that given the sample size and variance of the errors, the variance of the estimated parameters are affected by the spacing (increasing the variability of the right hand side variables) of the observed data. Therefore, increasing the spacing decreases the standard errors and increases the $t$-statistics for given estimated parameters. 
3. We used Chow-Lin technique based on the GDP calculations that uses the production side of the national income accounting for the interpolation. The State Statistical Institute uses three different methods to calculate the GDP: expenditure, production and income. In the VAR specifications, we used the GDP calculations after the statistical discrepancies are accounted for. However, for the interpolation we used the production-based GDPs. Therefore, we are not using the same information sets for the GDP and unemployment and we think that this does not create multi-collinerarity problems because the correlations among the GDP and unemployment for each education groups and gender are between -0.415 and 0.740 (These correlations are available from the authors on request).

4. For details of this procedure, see Christiano et al. (1999)

5. Bernanke and Blinder (1992) and Sims (1992) suggest the use of short-term interest rates rather than monetary aggregates as a measure of the monetary policy.

6. Impulse responses for six variables are available in a table format for interested readers on request.

7. In order to save space we classified Illiterate and Literate without any Diploma under less than primary school category and Vocational high school and High school under the High school category.

\section{References}

Acemoglu, D. (1998), "Changes in unemployment and wage inequality: an alternative theory and some evidence”, NBER Working Paper Series, No. 6658.

Agarwal, B. (1994), A Field of Her Own, Macmillan Press, Basingstoke.

Agenor, P.R. and Aizenman, J. (1999), "Macroeconomic adjustment with segmented labor markets", Journal of Development Economics, Vol. 58, pp. 277-96.

Algan, Y. (2002), "How well does the aggregate demand-aggregate supply framework explain unemployment fluctuations? A France-United States comparison”, Economic Modelling, Vol. 19, pp. 153-77.

Baker, D. and Schmitt, J. (1999), The Macroeconomic Roots of High European Unemployment: The Impact of Freign Growth, Center for Economic and Policy Research, Washington, DC.

Beneria, L. and Sen, G. (1981), "Accumulation, reproduction and women's role in economic development: Boserup revisited", Signs, Development and the Sexual Division of Labor, Vol. 7 No. 2, pp. 279-98.

Bergman, B. (1974), "Occupational segregation, wages and profits when employers discriminate by race and sex", Eastern Economic Journal, Vol. 1 Nos 1-2.

Bernanke, B. and Blinder, A. (1992), "Federal funds rate and the channels of monetary transmission”, American Economic Review, Vol. 82 No. 4, pp. 901-21.

Bernanke, B. and Mihov, I. (1998), "Measuring monetary policy", Quarterly Journal of Economics, Vol. 113 No. 3, pp. 869-902.

Berument, H. (2007), "Measuring monetary policy for a small open economy", Journal of Macroeconomics, forthcoming.

Berument, H. and Pasaogullari, M. (2003), "Effects of the real exchange rate on output and inflation: evidence from Turkey", Developing Economies, Vol. 41 No. 4, pp. 401-35.

Bulutay, T. (Ed.) (1996), "Education and the labour market in Turkey", State Institute of Statistics, Ankara, Proceedings of a Seminar Held in Ankara.

Cagatay, N. (1998), "Engendering macroeconomics and macroeconomic policies", Working paper No. 6, Social Development \& Poverty Elimination Division, New York, NY.

Central Bank of the Republic of Turkey (2004), available at: www.tcmb.gov.tr (accessed 10 March 2004).

\section{Economic performance}

621 
IJM

27,7

622
Christiano, L.J. (1991), "Modeling the liquidity effect of a money shock", Federal Reserve Bank of Minneapolis Quarterly Review, Vol. 15 No. 1, pp. 3-34.

Christiano, L.J. and Eichenbaum, M. (1992), "Identification and the liquidity effect of a monetary policy shock", in Cukierman, A., Hercowitz, Z. and Leiderman, L. (Eds), Political Economy, Growth and Business Cycles, MIT Press, Cambridge and London, pp. 335-70.

Christiano, L.J. and Eichenbaum, M. (1995), "Liquidity effects, monetary policy and the business cycle", Journal of Money, Credit and Banking, Vol. 27 No. 4, pp. 1113-36.

Christiano, L., Eichenbaum, M. and Evans, C. (1998), "Monetary policy shocks: what have we learned and to what end?", in Woodford, M. and Taylor, J. (Eds), Handbook of Macroeconomics, Volume 1a, Chapter 2, North Holland, New York, NY.

Cooley, T.F. and Hansen, G. (1989), "The inflation tax in a real business cycle model”, American Economic Review, Vol. 79 No. 4, pp. 733-48.

Cooley, T.F. and Hansen, G. (1997), "Unanticipated money growth and the business cycle reconsidered”, Journal of Money, Credit and Banking, Vol. 29 No. 4.

Daitoh, I. (2003), "Financial liberalization, urban unemployment and welfare: some implications of the artificial low interest rate and the high wage rate policies in LDCs", Journal of Development Economics, Vol. 72, pp. 163-79.

Eichenbaum, M. and Evans, C.L. (1995), "Some empirical evidence on the effect of shock to monetary policy on exchange rates", Quarterly Journal of Economics, Vol. 110 No. 4, pp. 975-1009.

Elson, D. and Pearson, R. (1981), "The subordination of women and the internationalization of factory production", in Young, K., Wolkowitz, C. and McCullogh, R. (Eds), Of Marriage and the Market, Routledge, London.

Ferber, M. and Birnbaum, B. (1977), "The 'new home economics': retrospects and prospects", Journal of Consumer Research, Vol. 4, pp. 19-28.

Ferber, M. and Nelson, J. (1993), Beyond Economic Man: Feminist Theory and Economics, University of Chicago Press, Chicago.

Folbre, N. (1982), "Exploitation comes home: a critique of the Marxian theory of family labour", Cambridge Journal of Economics, Vol. 6 No. 4, pp. 317-29.

Folbre, N. (1986), "Hearts and spades: paradigms of household economics", World Development, Vol. 14 No. 2, pp. 245-55.

Folbre, N. (1994), Who Pays for the Kids?, Routledge, New York, NY.

Gertler, M. and Gilchrist, S. (1994), "Monetary policy, business cycles and the behavior of small manufacturing firms", Quarterly Journal of Economics, Vol. 109 No. 2, pp. 309-40.

Hartmann, H. (1979), "Capitalism, patriarchy, and job segregation by sex”, in Eisenstein, Z. (Ed.), Capitalist Patriarchy and the Case for Socialist Feminism, Monthly Review Press, New York, NY.

Jackman, R., Layard, R., Manacorda, M. and Petrongolo, B. (1997), European versus US Unemployment: Different Responses to Increased Demand for Skill?, Discussion Paper No. 349, Center for Economic Performance, London.

King, R.G. (1991), “Money and business cycles”, Manuscript, University of Rochester, New York, NY.

Leeper, E.M., Sims, C.A. and Zha, T. (1996), "What does monetary policy do?”, Brookings Papers on Economic Activity, Vol. 2, pp. 1-63.

Neter, J., Wasserman, W. and Kutner, M.H. (1985), Applied Linear Statistical Models, 2nd ed., Richard D. Irwin, Homewood, IL.

Nickell, S. and Bell, B. (1995), "The collapse in demand for the unskilled and unemployment across the OECD", Oxford Review of Economic Policy, Vol. 11, pp. 40-62. 
Nickell, S. and Bell, B. (1996), "Distribution of wages and unemployment in OECD countries", American Economic Review, Vol. 86 No. 2, pp. 302-8.

Røed, K. (1999), "Relative unemployment rates and skill-biased technological change", Memorandum, No. 38/99, Department of Economics, University of Oslo, Oslo.

Sawhill, I. (1977), "Economic perspectives on the family", Daedalus, Vol. 106 No. 2, pp. 115-25.

Sen, A. (1990), "Gender and cooperative conflict", in Tinker, I. (Ed.), Persistent Inequalities, Oxford University Press, Oxford.

Sims, C. (1992), "Interpreting the macroeconomic time series facts", European Economic Review, Vol. 36, pp. 975-1011.

Sims, C.A. and Zha, T. (1995), "Does monetary policy generate recessions?”, Manuscript, Yale University, New Haven, CT.

Song, L. and Webster, E. (2001), "How segmented are skilled and unskilled labour markets: the case of Beveridge Curves", Working Paper No. 14/01, Melbourne Institute of Economic and Social Research, University of Melbourne, Melbourne.

State Institute of Statistics (2004), available at: www.die.gov.tr (accessed 10 March 2004).

Strongin, S. (1995), "The identification of monetary policy disturbances explaining the liquidity puzzle", Journal of Monetary Economics, Vol. 35, pp. 463-97.

Tansel, A. (2002), "Economic development and female labor force participation in Turkey: time-series evidence and cross-province estimates", in Bulutay, T. (Ed.), Employment of Women, State Institute of Statistics, Ankara.

Young, K., Wolkowitz, C. and McCullogh, R. (Eds) (1984), Of Marriage and the Market, Routledge, London (first published in 1981).

Zavodny, M. and Zha, T. (2000), "Monetary policy and racial unemployment rates", Economic Review, Vol. 85 No. 4, Federal Reserve Bank of Atlanta, pp. 1-16.

\section{About the authors}

Hakan Berument is an Associate Professor in the Department of Economics at Bilkent University. He received his $\mathrm{PhD}$ from the University of North Carolina in 1994. He was also director of the Research Department at the Central Bank of the Republic of Turkey. His research interests include sports economics, effectiveness of monetary policy and international transmission of international shocks. Hakan Berument is the corresponding author and can be contacted at: berument@bilkent.edu.tr

Nukhet Dogan is a research assistant in the Department of Econometrics at the Gazi University in Ankara since 1994. She received her MA and $\mathrm{PhD}$ from Department of Econometrics at the Gazi University.

Aysit Tansel is a professor of Economics at the Middle East Technical University (METU) in Ankara. She received her BS from METU with high honors, her MA from University of Minnesota and her PhD from State University of New York. She was a research fellow at the Yale University during 1990-1993. She is a fellow of the Institute for the Study of Labor (IZA) in Bonn and the Economic Research Forum (ERF) in Cairo. Her recent areas of interest include returns to education, private tutoring, labor force participation and unemployment.

\footnotetext{
To purchase reprints of this article please e-mail: reprints@emeraldinsight.com
} Or visit our web site for further details: www.emeraldinsight.com/reprints 